\title{
Grass pollen sensitization in dogs in Paraná, Brazil: comparison between percutaneous and intradermal testing
}

\author{
[Sensibilização a polens em cães no Paraná, Brasil: comparação entre o teste percutâneo \\ e o teste intradérmico] \\ A.P.S. Cerdeiro ${ }^{1}$, M.R. Farias $^{2 *}$, V.E.S. Cunha ${ }^{3}$, G.V. Sechi ${ }^{1}$, B.D. Pacheco ${ }^{1}$, \\ C.O.R. Alcalá ${ }^{1}$, R.G.R. Ganho ${ }^{4}$ \\ ${ }^{1}$ Aluna de pós-graduação - Pontifícia Universidade Católica do Paraná - Curitiba, PR \\ ${ }^{2}$ Pontifícia Universidade Católica do Paraná - Curitiba, PR \\ ${ }^{3}$ FDA Allergenic - Rio de Janeiro, RJ \\ ${ }^{4}$ Aluno de pós-graduação - Pontifícia Universidade Católica do Paraná - Curitiba, PR
}

\begin{abstract}
Canine atopic dermatitis is an inflammatory, genetic, pruritic and chronic dermatosis that affects between 10 and $30 \%$ of dogs and one of the most important allergens is grass pollen. The objective of this study was to evaluate the sensitization to grass pollen allergens in dogs with canine atopic dermatitis and to compare intradermal skin test (IDT) with percutaneous test (PT). For this study, ten healthy dogs and 39 dogs with atopic dermatitis were tested. Dogs were submitted to IDT and PT for Lolium multiflorum, Cynodon dactylon and Paspalum notatum. The IDT and PT tests were compared using the Proportion Test. All healthy dogs were negative to both tests. Ten atopic dogs $(25.6 \%)$ responded positively to the PT and none were positive in IDT. C. dactylon, L. multiflorum and P. notatum were responsible for positive reactions in $70 \%, 70 \%$ and $30 \%$ of positive dogs, respectively. The number of positive reactions in PT were statistically higher than IDT $(\mathrm{P}<0.05)$. In conclusion, grass pollen can be important source of allergens for dogs in Paraná state (Brazil) and the PT showed higher sensitization to grass pollen in dogs with atopic dermatitis than IDT.
\end{abstract}

Keywords: dogs, grass pollen, atopic dermatitis, prick test

\section{RESUMO}

A dermatite atópica canina é uma dermatose inflamatória, genética, prurítica e crônica que afeta entre $10 \%$ e $30 \%$ dos cães, e um dos alérgenos mais importantes são os polens de gramíneas. O objetivo deste estudo é avaliar a sensibilização a alérgenos de polens de gramíneas em cães com dermatite atópica e comparar o teste intradérmico (TID) com o teste percutâneo (TP). Para o estudo, 10 cães hígidos e 39 cães com dermatite atópica foram testados. Estes foram submetidos ao TID e ao TP para Lolium multiflorum, Cynodon dactylon e Paspalum notatum. TID e TP foram comparados usando-se o teste de proporção. Todos os cães hígidos foram negativos em ambos os testes. Dez cães atópicos (25,6\%) responderam positivamente ao TP e nenhum ao TID. C. dactylon, L. multiflorum e P. notatum foram responsáveis por reações positivas de 70\%, 70\% e 30\% dos cães positivos, respectivamente. O número de reações positivas no TP foi estatisticamente maior que no TID $(P<0,05)$. Foi concluído que os polens de gramíneas podem ser importantes fontes de alérgenos para cães no estado do Paraná (Brasil) e que o TP mostrou maior sensibilização a polens em cães com dermatite atópica que o TID.

Palavras-chave: cães, polens de gramíneas, dermatite atópica, teste percutâneo

\section{INTRODUCTION}

Canine atopic dermatitis (CAD) is a pruritic, inflammatory, and chronic dermatopathy, with a genetic predisposition, affecting between 10 and
$30 \%$ of the canine population (Carlotti, 2012). CAD results in the loss of the integumentary physical barrier function and increased immunoreactivity. It is estimated that approximately $80 \%$ of dogs with CAD have

Recebido em 29 de junho de 2020

Aceito em 6 de abril de 2021

*Autor para correspondência (corresponding author)

E-mail: marconi.puc@terra.com.br 
increased levels of the specific antibody immunoglobulin $\mathrm{E}$ ( $\mathrm{IgE}$ ), mainly as a response to environmental, microbial and food allergens (Pucheu-Haston et al. 2015). The environmental major allergens inducing CAD come from house dust mite allergens, weeds, shrubs, and grasses (Prélaud, 2014). In people with atopic dermatitis IgE mediated by extrinsic factors, it was found that exposure to grass pollens induces a significant worsening of cutaneous symptoms (Werfel et al., 2016).

The major allergenic grasses in south Brazil are Lolium multiflorum (LM) or Ryegrass, Cynodon dactylon (CD) or Bermuda grass, and Paspalum notatum (PN) or Bahia Grass. The subfamily Pooideae, to which belongs the LM, has the major allergens in groups 1 and 5 and may confer crossreactivity with other species of the same subfamily and with species of other subfamilies (Vieira, 2012). Among them, Lolium multiflorum is considered to be the most important allergen in humans in south Brazil (Rosário Filho, 2012). Veterinary studies to verify the incidence of pollinosis in Brazil are rare. A recent study that used intradermal skin test (IDT) in 58 dogs with atopic dermatitis in Rio Grande do Sul state, demonstrated a positive response to $\mathrm{CD}(24.13 \%)$, and PN (12\%) (Pereira et al., 2015). Sensitization to LM was not evaluated.

Percutaneos test (PT) has been used in medicine since its first description by Jack Pepys in 1975 as an alternative with lower risk of systemic reactions compared to IDT. Studies performed in cats and dogs showed papule reactions easier to interpret, no cutaneous and systemic reactions and good specificity (Rocha, 2012; Rossi et al., 2013, Gentry e Messinger, 2016). The objective of this study was to evaluate the sensitization to grass pollen allergens in dogs with CAD and to compare IDT with PT.

\section{MATERIAL AND METHODS}

The present study was approved by the Ethics Committee for the Use of Animals at the Pontifical Catholic University of Paraná (registry number: 1027/2016). It was a cross-sectional, non-randomized and controlled study. Ten healthy dogs, 5 females and 5 males, average age of 5 years, and 39 dogs with atopic dermatitis, 26 females, average age of 5 years, irrespective of breed, from the Pontifical Catholic University of
Paraná Veterinary Clinic School were included. There were not included in this study dogs that received antihistamines (1 week), oral and topical glucocorticoids (2 weeks) or long-term injectable glucocorticoids (4 weeks), according to Olivry's study of anti-allergic drugs optimal and minimal withdrawal times before allergic tests in dogs (2013). Females in estrus, gestation or lactation and dogs with chronic systemic diseases or with any other dermatopathy were also not included. All dogs in this study were submitted to the IDT and PT sequentially in the same day by the same examinator, who previously did a proficiency test as described by Cunha et al. (2015).

For IDT, the skin was shaved using a grooming machine and blade 40 in the lateral region of the thorax. After careful cleaning of the skin with a physiological solution, 10 application points were marked at an interval of $3 \mathrm{~cm}$ with a dermographic pen. For both groups, $0.9 \%$ phenolated saline and a histamine solution $(0.05 \mathrm{mg} / \mathrm{ml})$ were used as a negative and positive controls, respectively. Sensitization to pollen was evaluated using standardized extracts of LM, CD and PN at the concentration of $100 \mathrm{UBE} / \mathrm{ml}$. All extracts were supplied by FDA Allergenic (Rio de Janeiro, Brazil). The intradermal applications were performed using $0.5-\mathrm{ml}$ insulin syringes, attached to hypodermic needles $(13 \times 4,5 \mathrm{~mm})$, containing $0.05 \mathrm{ml}$ of each grass pollen extract. Fifteen minutes after application, the papules were marked with a dermographic pen to facilitate the reading. The cut-off value was established by calculating the mean for the negative control $(\mathrm{CN})$ and positive control $(\mathrm{CP})$ values. The responses to the tested antigens were considered positive when the mean diameter of the papules was $\geq$ the calculated cut-off value.

In the PT, histamine hydrochloride $(10 \mathrm{mg} / \mathrm{ml})$ and saline (containing $0.45 \%$ phenol) were used as the positive and negative control, respectively. Glycerinated allergenic extracts of LM, CD and PN were used at the concentration of 10.000 $\mathrm{UBE} / \mathrm{mL}$. All the extracts were supplied by FDA Allergenic (Rio de Janeiro, Brazil). After applying a drop of each extract or control solutions on the skin, the device (Duotip-test II ${ }$, Multi-test Brazil) was passed through the drop at a $45^{\circ}$ to $60^{\circ}$ angle to the skin. The skin was then gently lifted, creating a small break in the epidermis through which the suspected allergen solution penetrates. Then an absorbent paper was 
used to remove the excess of solutions. After 15 minutes, the test sites were observed, and the papules were evaluated. Papules that were at least $3 \mathrm{~mm}$ larger than the negative control were considered positive (Van der Valk et al., 2016). The results of the PT and IDT were compared in a descriptive way and then by the proportion test using the Minitab16 software (Minitab Inc., State College, Pennsylvania), with significance level set at $\alpha=0.05(\mathrm{P} \leq 0.05)$.

\section{RESULTS}

All dogs in Group 1 were negative to the allergen extracts in the IDT and PT. The mean histamine papule diameter in the IDT and PT was 15 and $7.45 \mathrm{~mm}$, respectively. The positive reactions in
PT ranged from 3 to $6 \mathrm{~mm}$, with formation of pseudopods in some cases. The comparison between papular histamine reaction in IDT and positive reaction to grass pollen in $\mathrm{PT}$ is shown in Figure 1. In DAC group, none of the dogs were positive for the pollen tested in IDT. Ten dogs $(25.6 \%)$ reacted to grass pollen with PT. Seven dogs $(18 \%)$ were positive to CD and LM, while three dogs $(7.7 \%)$ were positive to PN. Two dogs $(5.1 \%)$ reacted to three species tested and three dogs $(7.7 \%)$ to two species. Monosensitization was observed in five dogs $(12.8 \%)$ as shown in Table 1. The statistical analysis with Proportion Test showed that the PT was more effective in identifying sensitization to $\mathrm{CD}$ and $\mathrm{LM}$ $(\mathrm{p}=0,002)$, and PN ( $\mathrm{p}=0,036)$ compared to IDT.

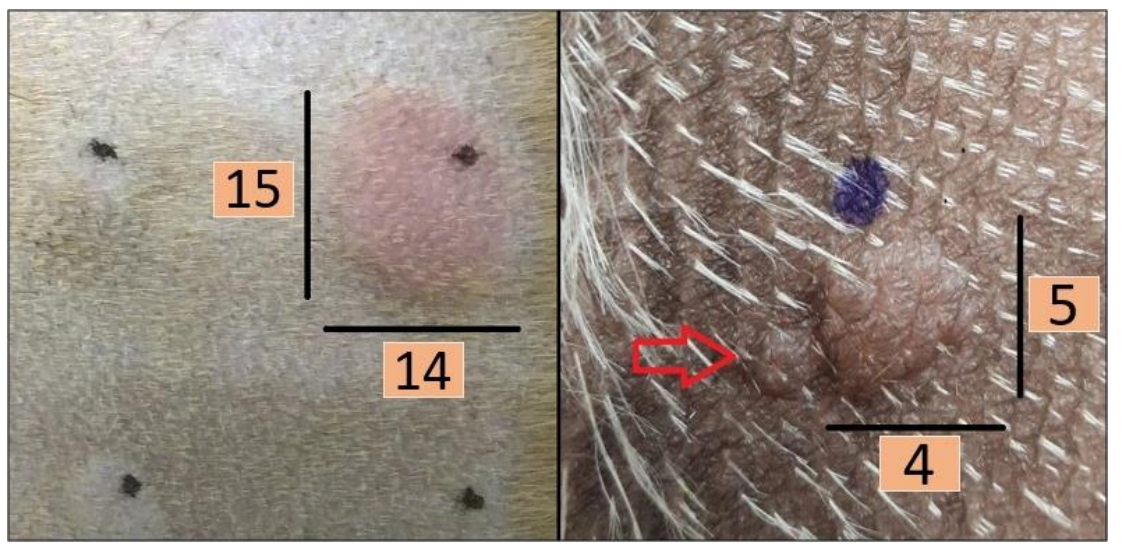

Figure 1. Comparison of papular histamine reaction in the intradermal test (left) and positive for grass pollen in the prick test (right) in millimeters. Note the formation of a pseudopod (arrow).

Table 1. Results of sensitization among ten reactive dogs in to grass pollen through the-Percutaneous Test

\begin{tabular}{lllllllllll} 
Pollen/Dog & 1 & 2 & 3 & 4 & 5 & 6 & 7 & 8 & 9 & 10 \\
\hline CD & + & - & + & + & - & + & + & + & - & + \\
LM & - & + & + & - & + & + & + & + & + & - \\
PN & - & - & - & - & - & + & + & - & - & + \\
\hline
\end{tabular}

$\mathrm{CD}$ - Cynodon dactylon; LM - Lolium multiflorum; PN - Paspalum notatum.

\section{DISCUSSION}

In the present study, the PT and IDT showed high specificity, justified by the lack of positive animals in the control group; these solutions were tested previously for irritative threshold in healthy dogs (unpublished data) and were tested again in this study to prove these findings. It is believed that IDT based on the irritation threshold have high specificity in the diagnosis of allergic sensitization (Hensel et al., 2004). It is estimated that the pollen sensitization in allergic people in
Brazil varies from $16 \%$ to $34 \%$, being more prevalent in the South and Center-West of the country (Vieira et al., 2011; Vieira, 2014; Sopelete et al., 2014). In dogs, the prevalence of grass pollen sensitization ranges from 10 to $27.7 \%$ (Masuda et al., 2000; Roussel et al., 2013). In Brazil, one study using IDT identified $10.3 \%$ of sensitization in atopic dogs using grass polens extracts (Pereira et al., 2015). In the present study using PT, the prevalence of sensitization to grass pollen was $(25.6 \%)$ and CD and LM were the most important species. 
This could be explained by the wide distribution of these species in the South region of Brazil, which can be found along roads, backyards, and parks (Viera, 2012). LM may provoke rhino conjunctivitis and allergic asthma in people (Rosário Filho, 2012) due to its wide distribution and an increase in its cultivation over the years. It has high allergenic potential due to its large-scale production and rapid spread in the wind (Bonissoni and Neto, 2014). In Curitiba, South of Brazil, a study done in 1999 found positive results using PT for LM in $4.7 \%$ of children aged 13 to 14 years and $15.4 \%$ of adults over 20 years of age (Esteves et al., 1999). A study conducted in 2002 found positivity for Lolium perene of $16.5 \%$ in skin allergic tests (Rosário Filho, 2002). In veterinary medicine, the incidence of sensitization to LM has not been evaluated so far and the present study revealed a positive response to this grass among atopic dogs (12.8\%) similar to previous findings.

Additionally, other species such as CD are allergenic and produce allergy symptoms beyond September and December (Rosário Filho, 2012). Sensitization to CD was detected in 16.8 and $80 \%$ of patients with rhinitis in Curitiba (Araújo et al., 2015) and Rio Grande do Sul (Vieira et al.., 2011), respectively. A previous study using IDT in Brazil found that $24.13 \%$ of atopic dogs were sensitized to CD (Pereira et al., 2015). In the present study, the positive response to this grass was similar to the other studies cited. The lowest incidence of positive response was observed with $\mathrm{PN}$. Positive reactions to $\mathrm{PN}$ were accompanied by positive reactions to $\mathrm{CD}$, suggesting the possibility of cross-reaction between these species. In dogs, the major allergens of grasses are yet to be identified; hence we could not test the hypothesis of cross-reaction between and PN in this study.

Among the ten animals with positive pollen responses through $\mathrm{PT}, 2$ were positive only to $\mathrm{CD}$, 2 to $\mathrm{CD}$ and LM, 2 to CD, LM and PN, 3 only LM and 1 to $\mathrm{CD}$ and PN. Therefore, there was no pattern of response suggestive of cross reactivity. The exception was the 3 PN positive dogs that were also $C D$ positive. However, 4 dogs were $C D$ positive but not PN positive. These results may indicate true sensitization to both species and cross reactivity between species, however suggesting that $\mathrm{CD}$ extracts may contain their own antigens. Due to the small number of positive tests $(n=10)$ and the heterogeneous pattern of responses, it was not possible to perform an adequate statistical analysis for evaluation of cross-reactivity among the species tested. For cross-reactivity studies, the ideal would be the use of immunochemical methods such as CrossInhibition ELISA, which is beyond the scope of this study.

The negative results in the present study can be explained by the sensitization to other environmental allergens, mainly from house dust mites species, species, as Dermatophagoides farinae, D. pteronyssinus and Blomia tropicalis, as shown by Cunha et al. in studies done in Brazil (Cunha et al., 2007; Cunha, 2012). Besides that, it is estimated that about $30 \%$ of patients with clinical diagnosis of atopic dermatitis have negative skin tests (Bauer et al., 2010). This suggests an innate, cellular inflammatory component that mediates pruritus development and symptoms related to atopic dermatitis in some patients, with no clear relation with sensitization and IgE formation (Halliwell, 2006). These findings could also explain some negative results observed. No systemic or local adverse reactions were observed in the PT and IDT, suggesting the safety of these tests in dogs. Some dogs presented only local effects characterized by pruritus and erythema, which disappeared in a few hours. In humans, the PT generates fewer adverse reactions than IDT, and fatal reactions can occur in the latter (Bernstein et al., 2008).

\section{CONCLUSION}

The prick test was more effective in identifying grass pollen sensitization in dogs with atopic dermatitis than the intradermal skin test. Sensitization to grass pollen occurred in about a quarter of the subjects and was more common to $\mathrm{CD}$ and LM through the prick test. Future studies are recommended to evaluate the efficacy of allergen-specific immunotherapy in dogs sensitized to these grass species.

\section{REFERENCES}

ARAÚJO, L.M.L.; ROSARIO, N.A.; MARI, A. Molecular-based diagnosis of respiratory allergic diseases in children from Curitiba, a city in Southern Brazil. Allergol. Immunopathol., v.44, p.18-22, 2015. 
BAUER, C.L.; HENSEL, P.; AUSTEL, M.; KEYS, D. Determination of irritant threshold concentrations to weeds, trees and grasses through serial dilutions in intradermal testing on healthy clinically nonallergic dogs. Vet. Dermatol., v.21, p.192-197, 2010.

BERNSTEIN, I.L.; LI, J.T.; BERNSTEIN, D.I. et al. Allergy diagnostic testing: an updated practice parameter. Ann. Allergy Asthma Immunol., v.100, p.S1-S148, 2008.

BONISSONI, E.; PASSOS NETO, J. O Lolium multiflorum associado ao aumento do consumo de anti-histamínicos. Visão Acad., v.15, p.81-99, 2014.

CARLOTTI, D.N. Clinical signs of canine atopic dermatitis and concurrent Diseases. In: WORLD CONGRESS OF VETERINARY DERMATOLOGY AND THE WORLD ASSOCIATION FOR VETERINARY DERMATOLOGY, 7., 2012, Bordeaux. Proceedings... Bordeaux: WAVD, 2012. p.58-66.

CUNHA, V.E.S. Serological identification of house dust mite allergens in dogs with atopic dermatitis. Pesqui. Vet. Bras., v.32, p.917-921, 2012.

CUNHA, V.E.S.; HAHNSTADT, R.L.; SOARES, A.M.B.; FACCINI, J.L.H. Evaluation of skin sensitivity in dogs bearing allergic dermatitis to standardized allergenic extract of house dust and storage mites. Pesqui. Vet. Bras., v.27, p.341-344, 2007.

CUNHA, V.E.S.; PEREIRA, D.T.; FARIAS, M.R. et al. Intradermal Test - Proficiency testing in dogs. In: CONGRESO LATINOAMERICANO DE DERMATOLOGÍA VETERINARIA, 3., 2015, Buenos Aires. Anales... Buenos Aires: [ASIS], 2015.

ESTEVES, P.C.; ROSÁRIO FILHO, N.A.; TRIPPIA, S.G.; CALEFFE, L.G. Sensibilização atópica em escolares e adultos de Curitiba, Paraná. Rev. Bras. Alergia Imunopatol., v.22, p.156-160, 1999.

FERNÁNDEZ-CALDAS, E. On mite allergy in dogs and humans. Int. Arch. Allergy Immunol., v.160, p.329-330, 2013.

GENTRY, C.M.; MESSINGER, L. Comparison of intradermal and percutaneous testing to histamine, saline and nine allergens in healthy adult cats. Vet. Dermatol., v.27, p.370-e92, 2016.
HALLIWELL, R. Revised nomenclature for veterinary allergy. Vet. Immunol. Immunopathol., v.114, p.207-208, 2006.

HENSEL, P.; AUSTEL, M.; MEDLEAU, L. et al. Determination of threshold concentration of allergens and evaluation of two different histamine concentrations in canine intradermal testing. Vet Dermatol., v.15, p.304-308, 2004.

MASUDA, K.; SAKAGUCHI, M.; FUJIWARA, S.; KURATA, K. et al. Positive reactions to common allergens in 42 atopic dogs in Japan. Vet. Immunol. Immunopathol., v.73, p.193-204, 2000.

OLIVRY, T. Evidence-bsed guidelines for antiallergic drug withdrawal times before allergenspecific intradermal and $\operatorname{IgE}$ serological tests in dogs. Vet. Dermatol., v.24, p.225-e49, 2013.

PEREIRA, D.T.; CUNHA, V.E.S.; SCHMIDT, C. et al. Sensitization study of dogs with atopic dermatitis in the central region of Rio Grande do Sul. Arq. Bras. Med. Vet. Zootec., v.67, p.15331538, 2015.

PRÉLAUD, P. Allergens and environmental influence. In: NOLI, C.; FOSTER, A.; ROSENKRANTZ, W. Veterinary allergy. Oxford: Wileey Blackwell, 2014. p.24-31.

PUCHEU-HASTON, C.M.; BIZIKOVA, P.; EISENSCHENK, M.N.C. et al. Review: the role of antibodies, autoantigens and food alleregens in canine atopic dermatitis. Vet. Dermatol., v.26, p.115-e30, 2015.

RANDALL, M.; HILLIER, A.; COLE, L.K. et al. Quantitation of house dust mites and house dust mite allergens in the microenvironment of dogs. Am. J. Vet. Res., v.64, p.1580-1588, 2003.

ROCHA, M.I.L. Skin prick tests - preliminary evaluation of this technique for the diagnosis of canine atopic dermatitis sensitization. 68f. 2012. 68f. Dissertation (Masters in Veterinary Medicine) - Technical University of Lisboa, POR.

ROSÁRIO FILHO, N.A. Alergia ao pólen de gramíneas: "back to the future". Rev. Bras. Alergia Imunopatol., v.35, p.82-84, 2012.

ROSÁRIO FILHO, N.A. Sensibilização atópica a aeroalérgenos em crianças asmáticas em Curitiba. J. Paranaense Ped., v.3, p.80-82, 2002. 
ROSSI, M.A.; MESSINGER, L.; OLIVRY, T.; HOONTRAKOON, R. A pilot study of the validation of percutaneous testing in cats. Vet. Dermatol., v.24, p.488-493, 2013.

ROUSSEL, A.J.; BRUET, V.; BORDEAU, P.J. Characterisation of $\operatorname{dog}$ sensitization to grass pollen in western France from 1999 to 2010. Vet. Rec., v.172, p.686, 2013.

SOPELETE, M.C.; JOSÉ VAZ, L.A.; TAKETOMI, E.A. Sensitization do Cynodon dactylon and Paspalum notatum grass pollens in pollinosis patients in Uberlândia, Minas Gerais. INTERNATIONAL SCIENTIFIC CONFERENCE, 2014, Rio de Janeiro. Proceedings... Rio de Janeiro: WAO, 2014. (Abstracts).

VAN DER VALK, J.P.M.; GERTH R.W.; HOORN, E. et al. Measurement and interpretation of skin prick test results. Clin. Transl. Allergy, v.6, n.8, 2016.
VIEIRA, F.A.M. Gramíneas tropicais alergênicas: Cynodon dactylon e Paspalum notatum - Uma visão para o trópico brasileiro. Rev. Bras. Alergia Imunol., v.35, n.1, 2012.

VIEIRA, F.A.M. Sensibilização polínica associada à polinose no trópico brasileiro: um desafio atual para o diagnóstico clínico. Braz. J. Allergy Immunol., v.2, p.81-82, 2014.

VIEIRA, F.M.; BRAGA, G.L.; FERREIRA, E.M. Cynodon dactylon e Paspalum notatum: revisar conceitos de sensibilização polínica por gramíneas no Sul do Brasil? Rev. Bras. Alergia Imunol., v.34, p.218-9, 2011.

WERFEL, T.; HERATIZADEH, A.; NIEBUHR, M. et al. Exacerbation of atopic dermatitis on grass pollen exposure in an environmental challenge chamber. J. Allergy Clin. Immunol., v.136, p.96-103, 2016. 